\title{
PEMETAAN KATEGORI DIMENSI SMART CITY BERDASARKAN RAGAM INOVASI APLIKASI DAN SITUS WEB MANAJEMEN PERKOTAAN DI INDONESIA
}

\author{
Mapping the Category of Smart City's Dimensions Based on the \\ Innovation of Applications and Websites for Cities Management in \\ Indonesia.
}

\section{Irsyad Adhi Waskita Hutama ${ }^{1}$, Achmad Djunaedi ${ }^{1}$}

\begin{abstract}
Penelitian ini termotivasi dari kemunculan konsep kota cerdas / Smart City (SC) yang telah diimplementasikan oleh beberapa kota besar di Indonesia seperti Jakarta, Bandung, dan Surabaya sebagai upaya untuk mengatasi permasalahan kota secara digital. Penggunaan teknologi informasi dan komunikasi (TIK) menjadi salah satu karakter penerapan $S C$ dengan banyak dikembangkannya inovasi $S C$ berupa aplikasi dan situs web. Terdapat lebih dari 338 inovasi terkait $S C$ yang dikembangkan dan diimplementasikan di kota-kota Indonesia, namun secara spesifik tercatat 109 inovasi yang berbentuk aplikasi dan situs web dengan cara kerja spesifik untuk mengatasi permasalahan kota. Dari 109 aplikasi/situs web, penulis mengkategorikan menjadi 14 kategori berdasarkan sifat kerjanya dalam mengatasi permasalahan kota yaitu lapangan kerja, transportasi/lalulintas, pendidikan, partisipasi masyarakat, pengelolaan lingkungan, birokrasi, perizinan, kepegawaian, kesehatan, manajemen energi, mitigasi bencana alam, kriminalitas, startup/kewirausahaan, dan pariwisata budaya. Pengelompokan tersebut menyimpulkan bahwa dimensi SC yang dikembangkan di Indonesia lebih komprehensif dari enam dimensi $S C$ oleh Giffinger et al (2007) dengan adanya modifikasi dimensi yaitu Smart Energy dan Smart Disaster Mitigation. Dimensi tersebut terdiri dari aplikasi/situs web mitigasi bencana alam dan pencegahan kriminalitas kota yang penerapannya masih terbatas. Penelitian ini dilakukan dengan pendekatan eksploratif kualitatif (reduksi dan pengkategorian data) dari sifat kerja aplikasi/situs web dalam mengatasi permasalahan dan manajemen perkotaan.
\end{abstract}

Kata kunci: Smart City; Inovasi; Aplikasi/situs web, TIK, Big data.

Abstract: This research is motivated from the emerging of Smart City (SC) concept which lately has been implemented in Indonesian's cities such as Jakarta, Bandung, and Surabaya as a mean to tackle city's problems digitally. The use of Information and Communication Technology (ICT) along SC becomes advance with the development of both applications and websites. About 338 SC's innovation accounted from cities in Indonesia but only 109 registered as applications or websites. From those numbers, we then categorize into 14 typologies of applications/websites based on its methods in tackling urban problems. They are job information, transport and traffic, education, citizen participation, environmental management, governance, bureaucracy/permission,

\footnotetext{
${ }^{1}$ Departemen Teknik Arsitektur dan Perencanaan, Fakultas Teknik, Universitas Gadjah Mada
} 
staffing, health, energy management, disaster mitigation, criminality, entrepreneurship, and culture and tourism. As result, those categorizations are, in fact, more comprehensive than those of Giffinger's six smart city dimensions (Giffinger et al., 2007) by adding two more dimensions namely Smart Energy Management and Smart Disaster Mitigation. Despite the availability of the applications and websites related to them, yet the implementation is still limited. The explorative and qualitative approach was used as research method involving secondary data collection, categorization scheme, and pairing to Giffinger's $S C$ dimensions.

Keywords: Smart City, Innovation, Applications/websites, Information and Communication Technology (ICT), Big Data.

\section{PENDAHULUAN}

Perkembangan kota yang relatif pesat berbanding lurus dengan semakin meningkatnya kompleksitas permasalahan kota yang terjadi hampir disemua sektor (sosial/demografi, transportasi, infrastuktur, energi, dan kepemerintahan). Kondisi saat ini, terdapat 3,9 juta jiwa yang tinggal di kota atau lebih dari 54\% total penduduk dunia tinggal di kota. Fenomena ini diprediksi akan terus meningkat hingga 6 juta populasi pada tahun 2045 (UN-Habitat, 2006). Progres ini berdampak pada meningkatnya permintaan terhadap energi, sumber daya air, lahan, dan pelayanan dasar perkotaan yang mencukupi. Solusi atas desakan perkembangan perkotaan yang pesat dan teknologi yang ada saat ini memunculkan perlunya pelayanan infrastruktur kota yang cerdas sebagai solusi untuk permasalahan perkotaan yang semakin kompleks (Finger, 2017).

Kota cerdas atau smart city (SC) merupakan istilah yang sering digunakan (buzzword) dan menjadi label yang disematkan untuk kota-kota yang sudah menggunakan teknologi informasi dan komunikasi (TIK), jaringan internet, dan sensor untuk membantu mengumpulkan data dalam jumlah besar (big data), menganalisis secara cepat, dan memberikan alternatif solusi untuk mengatasi permasalahan kota dalam waktu yang relatif singkat dan terkini/realtime (Hollands, 2008). Konsep kota pintar bertolak dari ditetapkannya digital city of Amsterdam pada tahun 1994 dan Geneva-MAN dimana teknologi internet digunakan untuk pertama kalinya oleh masyarakat secara luas (Graham \& Aurigi, 1997). Saat ini perkembangan teknologi informasi dan komunikasi, Internet of things (IOT), sensor, dan peranti lunak smart phone telah banyak dikembangkan sebagai perwujudan dari implementasi SC. Anthopoulos (2016) menyatakan kurang lebih ada 10 kota di dunia yang melabelkan dirinya sebagai kota cerdas dengan berbagi macam inovasi seperti jejaring internet/webserver, pemasangan sensor, dan pengembangan aplikasi. Sebagai contoh, Kota London melalui Smart London Board (2013) meluncurkan beberapa aplikasi dan situs web untuk menunjang beberapa sektor pelayanan kota seperti bisnis dan wisata (http://cityoflondon.gov.uk/Pages/ dan (http://citydashboard.org/london/) dan data terbuka geospasial Kota London (data.london.gov.uk).

Di Indonesia, kota-kota besar melabelkan dirinya smart seperti Bandung, Jakarta, Surabaya, dan terakhir Kota Yogyakarta yang sedang dalam tahap studi dan inisiasi $S C$. Beberapa aplikasi dan situs web telah dirilis seperti "PetaBencana.id" (BPBD Jakarta, 2015), Media Social Mapping, dan X-Igent Panic Button. Saat ini perkembangan dan implementasi $S C$ berkorelasi dengan munculnya berbagaimacam startup inovasi berupa aplikasi maupun situs web yang memiliki fungsi spesifik untuk memecahkan permasalahan dan manajemen perkotaan. Pada ujungnya, $S C$ berusahan untuk mencapai efisiensi dan efektifitas pemanfaatan sumber daya yang dikomsumsi oleh sebuah kota untuk menuju pembangunan berkelanjutan (Sofeska, 2017). Disamping itu, tujuan dari SC dalam konteks perencanaan kota adalah mengetahui (sensing) kondisi saat ini dengan data yang terhimpun untuk menentukan pengambilan keputusan yang tepat, sehingga $S C$ bersifat 
solutif dalam mengatasi permasalahan kota dan mentukan rekayasa perencanaan ke depannya (Crooks et al., 2015; Geertman et al., 2015).

Berangkat dari fenomena perkembangan TIK dan urgensi manajemen kota secara digital tersebut di atas, penelitian ini secara garis besar termotivasi untuk mengeksplorasi aplikasi/situs web $S C$ dan bagaimana cara kerja untuk mengatasi permasalahan kota. Penulis mengajukan pertanyaan penelitian yaitu (1) Seperti apakah ragam aplikasi dan situs web pendukung $S C$ yang digunakan di kota-kota di Indonesia? (2) Seperti apakah wujud dimensi smart city yang ada di Indonesia berdasarkan kategori aplikasi/situs web manajemen perkotaannya. Penelitian ini disusun dalam struktur penulisan yaitu bagian pertama memberikan motivasi mengapa penelitian ini dilakukan. Selanjutnya penjelasan terhadap tinjauan pustaka yang relevan terkait konsep $S C$ dalam konteks manajemen perkotaan, Smart City, IoT, dan big data, dan wujud dari IoT berupa aplikasi dan situs web. Bagian ketiga menjelaskan pendekatan kualitatif dan ekploratif sebagai metode dalam penelitian, dan dilanjutkan dengan hasil serta pembahasan terkait pemetaan ragam aplikasi/situs web. Terakhir, kesimpulan diberikan disertai dengan rekomendasi untuk penelitian kedepannya.

\section{TINJAUAN PUSTAKA}

\section{Smart City dan Manajemen Perkotaan}

Smart City (SC) dapat diartikan sebagai suatu konsep manajemen perkotaan yang efisien dan efektif dengan mengupayakan penggunaan teknologi informasi dan komunikasi (Hollands, 2008; Picon, 2015). Konsep ini bekerja dengan menggabungkan dunia digital dengan dunia fisik melalui jejaring komunikasi nir kabel yang diimplementasikan kedalam segi kehidupan kota seperti kepemerintahan, pelayanan publik, infrasturktur, energi, dan lingkungan. Arup (2010, hal. 3) mengatakan tujuan positif dari implementasi SC dalam kerangka pembangunan dan manajemen perkotaan adalah (1). Membangun ekonomi kreatif dan terciptanya lapangan kerja; (2) Mendorong efisiensi sumber daya dan memitigasi perubahan iklim; (3) Menyediakan ruang untuk hidup dan kerja yang lebih lapang (dunia virtual); 4) Kota menjadi lebih efisien; (5) Mendukung berkembangnya komunitas yang adil, kreatif, dan partisipasif.

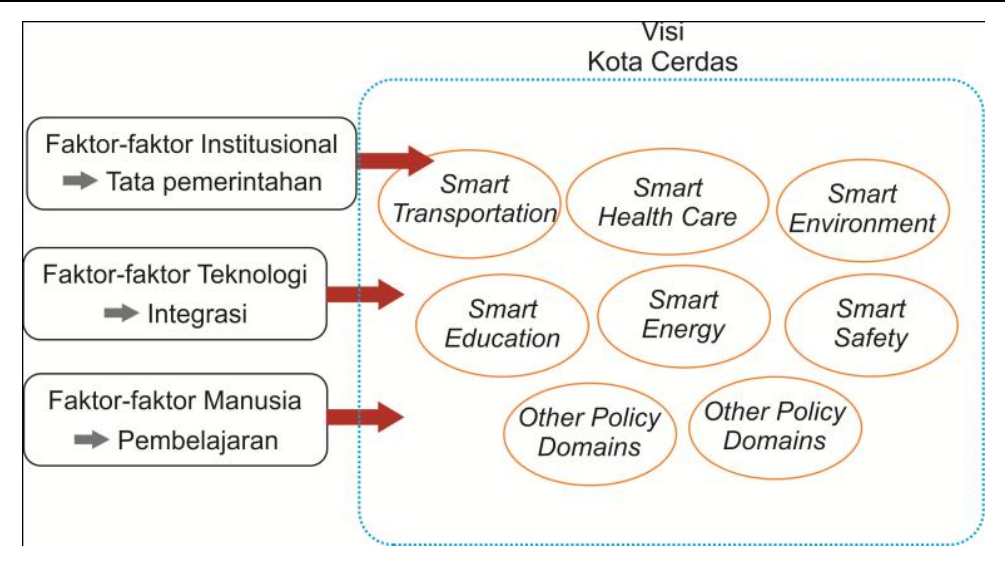

Gambar 1. Tiga Pilar Komponen Pengembangan Smart City (Nam \& Pardo, 2011: hal 288)

Nam dan Pardo (2011) mengamati bahwa SC tidak hanya dilihat dari keberadaan hardware seperti sensor dan teknologi informasi tetapi lebih pada kepekaan user dan enabler (individu/pemerintah) terhadap keberadaan konsep $S C$ yang telah diterapkan di kota mereka. 
Kepekaan terhadap SC ini meliputi dimensi manusia, institusional, dan teknologi (aplikasi/tools, ICT, IoT). Berdasarkan penelitian Anthopoulos (2016) pada 10 kota di negara maju, masyarakat/ resident menyatakan sadar (aware of) jika kotanya tergolong cerdas dengan keberadaan ekosistem $S C$ yang meliputi aplikasi, smart agenda, dan data terbuka yang mampu diakses publik.

Perkembangan SC sejalan dengan berkembangnya TIK dan IoT. Dalam implementasinya, smart city memerlukan peranti lunak dan keras untuk memonitor dan menganalisis data kota. Lv, Song, Basanta-Val, Steed, \& Jo (2017) mengemukakan kota cerdas berhubungan dengan big data dimana arus informasi begitu besar (massive), cepat, dan diproses (analisis dan visualisasi) secara tepat. Dari sisi ini, informasi yang ditangkap baik oleh aplikasi dan sensor harus dapat diolah secara otomatis dan ditampilkan secara representatif (data summary visualization) untuk memberikan masukan kepada para pengambil keputusan. Makna cerdas dalam SC merujuk pada pada inisiastif dan partisipasi dari stakeholders dalam merespon informasi dan mengambil keputusan yang tepat (Mayangsari \& Novani, 2015).

\section{Internet of Things dan Aplikasi Pendukung Smart City}

Ekosistem hibrid dunia fisik dan digital yang didukung oleh TIK yang modern memungkinkan (enabling) perkembangan konsep dan implementasi SC secara pesat diabad 21 (Kunzmann, 2014). Eksploitasi TIK seperti jaringan nir kabel (WIFI/WIMAX), internet/ web service, sensor/aktuator merupan prasyarat terbentuknya ruang digital yang mampu berinteraksi antara satu sistem dengan sistem lainnya. Dalam konteks $S C$, keberadaan TIK berhubungan erat dengan produk IoT yang menjembatani dunia digital dengan dunia nyata (Rathore et al., 2016).

Keberadaan $S C$ dan IoT dibarengi dengan kemunculan beragam jenis aplikasi dan situs web yang secara spesifik dikembangkan untuk mendekatkan kebutuhan masyarakat dengan segi kehidupan kota. Pengembangan aplikasi/situs web sejalan dengan visi SC yang kemudian dijabarkan dalam enam dimensi kota cerdas (Giffinger et al., 2007). Sebagai contoh, terdapat inovasi aplikasi yang memungkinkan masyarakat berpartisipasi memberikan data informasi dalam pelayanan publik, kondisi lalu lintas dan alternatif rute yang dapat diambil, melaporkan kejadian kriminalitas atau kejadian penting yang terjadi di kota, melakukan pengecekan skedule dan rute transportasi publik, manajemen dan monitoring energi, memitigasi terjadinya kriminalitas perkotaan, menginformasikan lowongan pekerjaan/kursus, manajemen dan mitigasi bencana maupun kriminalitas, hingga pelayanan kesehatan yang dapat dilakukan dengan aplikasi/situs web.

Diversitas inovasi aplikasi dan situs web dapat dikelompokkan pada basis dimensi $S C$. Fungsi aplikasi/situs web dalam dimensi $S C$ dapat dielaborasikan sebagai berikut:

- Smart Economy - berkaitan dengan promosi sumber daya manusia (SDM) dan kemampuan untuk mempertemukan SDM dengan kegiatan ekonomi yang sesuai dengan spesifikasi, jenis, dan skalanya (Sarma \& Sunny, 2017). Kegiatan ekonomi berbasis berbagi modal ekonomi (sharing economic) seperti Airbnb, tokopedia, Gojek/Grab merupakan inovasi bisnis yang menggunakan konsep ini.

- Smart Governance - meliputi aplikasi/situs web yang memungkinkan terjadinya interaksi dan partisipasi antara stakeholders, meningkatkan kapasitas pelayanan publik dan transparansi publik terhadap kegiatan dan penganggaran.

- Smart People/Community - dijabarkan melalui aplikasi/situs web yang memberikan kesempatan bagi masyarakat untuk pengembangan diri dan aktualisasi diri, mengintegrasikan kehidupan sosial dengan aktifitas di ruang kota. Sebagai contoh, aplikasi/situs web mengenai acara budaya/ethical, event khusus, hingga pengenalan kelompok/komunitas yang memiliki ketertarikan positif di ruang kota. 
- Smart Mobility - meliputi inovasi aplikasi/situs web yang mampu memonitor pergerakan kendaraan atau barang dalam sistem transportasi kota. Aplikasi memungkinkan individu untuk mengetahui kondisi lalu lintas, alternatif rute, dan juga jadwal publik transportasi kota.

- Smart Environment - berkaitan dengan kemampuan aplikasi untuk memonitor dan merasakan perubahan variable lingkungan seperti polusi udara, suhu udara, kualitas air, dan kebisingan.

- Smart Living - berhubungan dengan peningkatan kualitas hidup masyarakat (Quality of Life) seperti berwisata, kesehatan, dan amenities kota, hingga level mikro yaitu pemanfaatan IoT pada infrastruktur rumah atau bangunan yang cerdas.

- Smart Disaster Manajemen - Berhubungan dengan manajemen dan kontrol terhadap bencana baik alam maupun kriminalitas. Hal ini diantaranya adalah pemanfaatan IoT seperti sistem monitoring menggunakan CCTV di ruang kota, dan pada ruang-ruang rawan kriminalitas serta sistem peringatan dini bencana alam.

\section{Cara Kerja Aplikasi dalam Ekosistem Smart City}

Smart city berbasis IoT memiliki fungsi dan cara kerja yang spesifik untuk menyelesaikan permasalahan kota. Ditinjau dari cara kerja sistem tersebut, terdapat kesamaan umum dimana data spasial dan atau data atribut dikoleksi melalui sensor/aplikasi/situs web kemudian diseleksi (filtering) dan dikategorikan. Selanjutnya data dianalisis (data analytic), divisualisasikan dan diintepretasikan (visualization and interpretation). Proses selanjutnya, data direspon berdasarkan kecenderungan (trend) yang mungkin terjadi ke dalam beberapa skenario alternatif untuk pengambilan keputusan (Rathore et al., 2016). Implementasi SC bergantung pada pendekatan sistem terpusat dimana data dalam jumlah besar terkoleksi dari beberapa sumber sensor menuju basis data, diproses, dan kemudian kembali pada masyarakat melalui infrastruktur digital (Murty et al., 2008). Konsep ruang digital (digital space) yang terkoneksi dengan infrastruktur teknologi wireless menjadi fundamental bagi implementasi SC (Picon, 2015). Ruang digital merupakan wujud hybrid dari ruang fisik (physical world) yang diinterpretasikan dalam bentuk abstraksi data yang bervariasi (contoh: visual, geolocation, social data, dan lainlain). Hal ini memungkinkan kehidupan kota yang dinamis dapat direkam dan diinterpretasikan dalam waktu yang hampir bersamaan (near or real time).

$S C$ bekerja dalam ekosistem komputasi yang luas dimana sensor/aplikasi/situs web mengkoleksi data dalam jumlah besar. Aplikasi/situs web yang canggih menambahkan fitur interaktif dua arah dimana user dapat memberikan dan menerima respon dari penyedia informasi (Cicirelli et al., 2017). Penerapan sistem ini memungkinkan adanya interaksi dalam dunia digital yang sebenarnya dapat dianalisis terkait pola spasial, sebaran data, maksud (sentiment), dan tanggapannya. Sebagai contoh adalah aplikasi yang memiliki fitur geolocation dan pemberiaan informasi seperti petabencana.id, Qlue, dan aplikasi pelayanan/pengaduan publik lainnya. Berbeda dengan sistem di atas, aplikasi/situs web dengan fitur interaksi satu arah terbatas pada kemamuan untuk merasakan (sensing) dimana informasi dari penyedia hanya dapat dibaca oleh user tanpa ada respon umpan balik. Hal ini banyak ditemukan pada situs web pemerintah daerah terkait data daerah, informasi pelayanan, dan transportasi publik.

Untuk mengimplementasi $S C$ berbasis IoT (aplikasi/situs web), diperlukan adanya sistem utuh (complete system) yang saling terintegrasi. Sistem ini terdiri dari empat bagian (Rathore et al., 2016) yaitu:

1. Tingkat dasar (bottom tier) - yaitu sub-sistem yang bertanggungjawab untuk mengumpulkan atau menghasilkan data. Alat (device) ini bisa disebut sensor yang dipasang di lingkungan kota seperti jalan, tempat parkir, taman, mall, dan lain-lain. 
Alat berupa sensor ini juga bisa berbentuk aplikasi pada ponsel pintar dimana informasi spesifik dapat di bangkitkan oleh individu untuk tujuan dan kondisi tertentu (citizen as sensor).

2. Tingkat menengah ke-I (Intermediate tier-1) - yaitu sub-sistem yang bertanggungjawab untuk mengkomunikasikan data dari sensor - server data - data di awan (cloud storage) - dan web-server. Hal ini memerlukan jaringan nirkabel/internet, 3G, 4G/LTE, WIFI sehingga sub-sistem ini disebut IoT dimana segala sesuatu terhubung satu sama lain dalam platform TIK.

3. Tingkat menengah ke II (Intermediate tier2) - yaitu sub-sistem yang bertanggung jawab sebagai data manajemen dan memproses data. Hal ini dilakukan pada satu atau beberapa database yang saling terintegrasi. Pada umumnya sistem manajemen data besar (big data) dilakukan dalam peranti lunak HADOP-HDFS / Posgre SQL / Map Reduce yang memungkinkan mengolah data dalam jumlah besar dalam format yang berbeda-beda. Pada tingkatan ini, analisis data menggunakan pendekatan automasi analisis data seperti metode machine learning, user behavior prediction, neural network analysis, dan natural language processing (NLP) untuk analisis berbasis data text (Lv et al., 2017).

4. Tingkat atas (top tier) - yaitu sub-sistem yang bertanggung jawab untuk melakukan intepretasi dan visualisasi data. Tahap ini kembali dapat berbentuk aplikasi/situs web tematik yang menampilkan informasi spesifik. Seperti aplikasi Qlue yang menampilkan sebaran kejadian (event) pada peta dengan informasi spatial yang terkoordinat.

\section{METODE PENELITIAN}

Penelitian ini dilakukan dengan pendekatan kualitatif dan eksploratif dimana data aplikasi dan situs web dikoleksi, kemudian dianalisis dengan mengkategorikan informasi kedalam sifat/cara aplikasi/software dalam mengatasi permasalahan dan mengelola kota. Dalam hal ini, peneliti mencoba mengetahui fungsi serta bagaimana ekosistem kerja aplikasi/situs web dalam konteks interaksi data, pemerintahan (governance), dan pengguna (user). Selanjutnya, peneliti memasangkan kategori aplikasi dan situs web dalam enam dimensi $S C$ Giffinger et al., (2007) untuk mengetahui dan memberikan rekomendasi modifikasi dimensi $S C$ yang ada di Indonesia.

\section{Cara Pengumpulan Data Aplikasi dan Situs Web}

Data dalam penelitian ini berhubungan erat dengan penggunaan IoT dimana data dikoleksi melalui sensor-sensor keras dan lunak dan ditampilkan dalam media yang berbentuk aplikasi dan atau situs web. Rathore et al. (2016) menyatakan, data sekunder mengenai aplikasi dan dataset terkait SC didapatkan dari berbagai sumber resmi yang membuka arus informasi datanya untuk dapat diakses secara publik. Unit amatan dalam penelitian ini adalah data berupa aplikasi dan situs web sebagai wujud implementasi konsep smart city untuk manajemen kota. Data diperoleh melalui survei terhadap sumbersumber informasi diantaranya instansi terkait yang berhubungan langsung dengan SC (CFDS UGM, Gama Techno, Bandung Command Center), penelitian ilmiah, pekerjaan proyek/kajian $S C$, dan internet.

Pada tahap pengumpulan data, aplikasi dan situs web yang diperoleh dari berbagai sumber, disertai dengan informasi detail meliputi nama aplikasi, kota atau kabupaten dimana aplikasi dioperasikan, platfrom aplikasi, alamat situs web (informasi) yang menyertai, bidang inovasi, pengembang (developer) aplikasi, dan fungsi sederhana (lihat Tabel 1). Review kajian terkait konsep $S C$ yang telah diinisiasi dan implementasi di kota besar seperti Bandung (Pandini, 2016), menjelaskan adanya Bandung Command Center 
sebagai pusat manajemen informasi dan adanya sejumlah aplikasi/situs web seperti surat online, BIRMS (Bandung Integrated Resources Management System), DPMPTSP, Panic Button, dll. Studi terkait $S C$ di Surabaya mengemukakan bahwa kota tersebut telah menerapkan sebagian konsep $S C$ dengan mewujudkan media center dalam pelayanan publik (Anggini, 2016). Hal tersebut dapat dijalankan dengan adanya aplikasi dan situs web seperti e-surat, e-musrembang, solid waste application (SWAT) dan lain-lain sesui dengan bidang kerja pelayanan publik. Studi lain juga menjelaskan penggunaan IoT aplikasi/situs web yang tidak bisa lepas dari implementasi $S C$ di Indonesia.

Aplikasi/situs web juga dikoleksi dari proyek-proyek yang relevan seperti penilaian kesiapan dan inovasi dari pemerintah daerah menuju $S C$. Koleksi data selanjutnya ditindaklanjuti dan divalidasi melalui pengunduhan (download) langsung di Google Play store atau App Store untuk mengetahui keberadaan, fungsi, dan bagaimana aplikasi tersebut bekerja. Hal yang sama, situs situs web dilacak untuk megetahui hal serupa di atas. Hampir semua aplikasi yang diunduh bersifat bebas bayar.

Dari hasil survei hingga akhir bulan Oktober 2017, terkoleksi 338 Aplikasi dan situs web yang digunakan beberapa kota di Indonesia. Jumlah tersebut bukan menunjukkan angka pasti dimana terdapat kemungkinan besar aplikasi/situs web yang belum teridentifikasi karena keterbatasan waktu dan sumber dana. Dari 338 data yang terhimpun, lebih dari $65 \%$ berupa situs web inovasi pemerintah kota/daerah untuk mengatasi permasalahan dan manajemen kota/daerah.

\section{Cara Mengkategorisasikan Aplikasi/Situs Web Smart City}

Aplikasi/web site memiliki karakter dan fungsi yang bervariasi. Pemetaan dilakukan dengan melihat fungsi dan cara kerja tiap aplikasi/software untuk majemen maupun solusi permasalahan kota. Sebagai contoh aplikasi $X$-Igent bekerja dengan cara melaporkan kondisi bahaya yang dialami oleh pengguna melalui aplikasi sehingga informasi lokasi, waktu, dan kejadian dapat ditransmisikan dan diketahui oleh tim khusus di Bandung Command Center (BCC). Dilihat dari fungsinya, aplikasi ini dirancang untuk memitigasi kriminalitas perkotaan. Untuk itu aplikasi ini dikategorikan (orde-I) sebagai pencegah/mitigasi kriminalitas. Prinsip yang sama juga diimplementasikan pada semua aplikasi/situs web untuk menemukan kategori inovasi seperti mitigasi bencana alam, transportasi massal, penyediaan lapangan pekerjaan, pariwisata, kesehatan, manajemen energi, lingkungan, dan lain-lain.

Selanjutnya, dari kategori inovasi (orde-I) dipasangkan ke dalam komponen dasar SC menurut Giffinger et al., (2007). Pemasangan kategori aplikasi dan situs web didasarkan pada kesamaan cara kerja inovasi tersebut dalam mengatasi permasalahan kota. Sebagai contoh, kategori (orde-1) inovasi seperti transportasi publik dan lalu lintas dipasangkan dengan dimensi Smart Mobility (orde-II), kategori pariwisata dan kesehatan dipasangkan dengan dimensi Smart Living dan seterusnya. Dari proses ini diperoleh penambahan/modifikasi dua dimensi SC yaitu Smart Energy Management dan Smart Disaster Management.

Deskripsi cara kerja aplikasi/situs web untuk manajamen dan mengatasi permasalahan kota diambil dari pengelompokan inovasi (orde-II) dengan asumsi secara umum aplikasi tersebut memiliki cara kerja teknis yang relatif sama. Untuk hal ini, dipilih 109 aplikasi/situs web yang telah divalidasi ke sumbernya. Justifikasi dari pemilihan aplikasi adalah dilihat dari penggunaannya yang sebagian besar diambil dari contoh kotakota besar seperti Jakarta, Bandung, Surabaya dan popularitas aplikasi/situs web dari adanya publikasi media. 


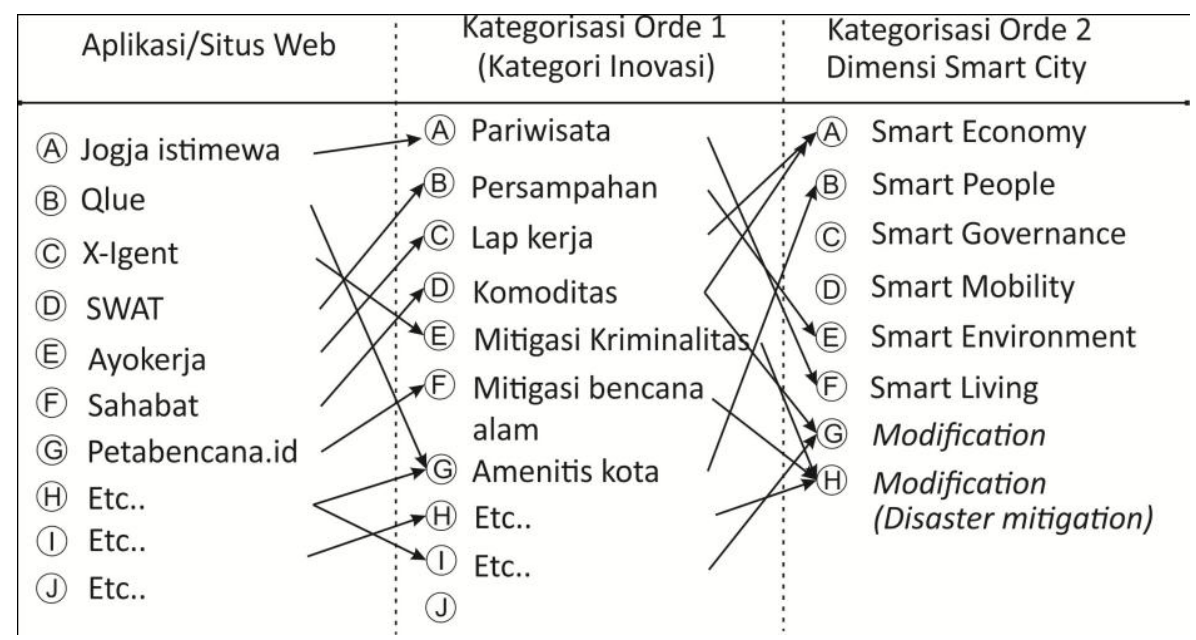

Sumber: Analisis, 2018

\section{Gambar 2. Cara Mengkategorisasikan Aplikasi/Situs web Smart City dari Orde I ke Orde II}

\section{HASIL DAN PEMBAHASAN}

\section{Aplikasi dan Situs Web Smart City untuk Manajemen Perkotaan}

Aplikasi/situs web merupakan salah satu modul diseminasi informasi SC yang langsung terhubung dengan pengguna (user). Di Indonesia secara keseluruhan tercatat kurang lebih 338 inovasi SC yang terdiri dari 96 inovasi di bidang Smart Economy, 22 inovasi berkaitan dengan Smart Mobility, 28 inovasi tentang Smart People, 39 inovasi terkait Smart Environment, 71 Aplikasi terkait Smart Governance, dan 76 inovasi terkait Smart Living. Melimpahnya inovasi pendukung SC mengindikasikan bahwa beberapa kabupaten dan kota di Indonesia telah mengetahui dan mencoba untuk menerapkan konsep smart city untuk membantu pelayanan dan mengelola kotanya. Inovasi $S C$ yang cukup banyak dikembangkan adalah Smart Economy, Smart Governance, Smart Living, dan Smart Mobility. Inovasi Smart Economy berkaitan dengan informasi lowongan pekerjaan/ketenagakerjaan, peluang usaha (entrepreneur), dan peningkatan produktifitas (contoh: pertanian, komoditas) dan creative start up. Smart governance bagi kota-kota seperti Surabaya dan Bandung merupakan contoh dimana pelayanan publik yang terpusat telah dilaksanakan secara cerdas dengan TIK dan aplikasi. Hal ini yang turut mempelopori kota-kota lain untuk menginisiasikan $S C$ dari sisi tata kelola pemerintahan dan pelayanan publik terlebih dahulu. Menghubungkan masyarakat dengan tata kelola kepemerintahan melalui TIK merupakan langkah awal keberhasilan implemetasi $S C$ sebelum beranjak ke dimensi yang lebih luas (Mayangsari \& Novani, 2015; Nam \& Pardo, 2011), sedangkan untuk Smart Living yang telah berkembang di Indonesia meliputi inovasi aplikasi pariwisata, kegiatan budaya, dan kesehatan.

Secara keseluruhan data inovasi SC, hanya sekitar 109 inovasi yang berbentuk aplikasi dan atau situs web. Aplikasi tersebut kemudian dikelompokkan dalam perspektif cara kerja dalam solusi permasalahan kota. Dari 109 aplikasi terpilih, dapat dikelompokkan ke dalam 14 kategori yaitu inovasi aplikasi/situs web bidang transportasi, kesehatan, pendidikan, kewirausahaan dan lapangan pekerjaan, birokrasi dan tata pamong, partisipasi masyarakat, pengelolaan sampah, perizinan, energi, mitigasi bencana alam, mitigasi kriminalitas, dan pariwisata/budaya/ event khusus, dan lainnya (lihat Tabel 2).

Dilihat dari sisi kuantitas inovasi aplikasi/situs web yang dikembangkan, tergambarkan bahwa kategori birokrasi/kepemerintahan (17 items), partisipasi masyarakat (11 items), dan perizinan (10 items) merupakan inovasi yang banyak diciptakan pada skala 
kota/kabupaten di Indonesia. Pada kota besar seperti Bandung terdapat kurang lebih 10 aplikasi/situs web terkait birokrasi dan kepemerintahan, sedangkan Kota Surabaya terdapat 13 unit. Hal ini mengindikasikan bahwa implementasi konsep SC di Indonesia berawal dari optimalisasi pelayanan publik dan tata kelola kepemerintahan dengan menggunakan modul TIK. Hasil empiris ini diperkuat oleh Mutiara et al., (2018) yang menyatakan bahwa sebagian besar inovasi $S C$ terkait dimensi kepemerintahan. Secara spesifik untuk dimensi ini, figur pemimpin, kesiapan sumber daya perangkat pemerintah, dan pemanfaatan TIK menjadi kunci keberhasilan implementasi Smart Governance pada kasus Kota Surabaya (Anggini, 2016). Inovasi aplikasi/situs web yang secara kuantitas paling sedikit adalah manajemen energi. Keterbatasan teknologi dan sensor dalam memonitor pemanfaatan, perubahan, dan beban infrastruktur energi menjadi penyebab masih minimnya inovasi Smart Energy di Indonesia.

Tabel 1. Daftar Aplikasi dan Situs web Inovasi Smart City untuk Manajemen Kota

\begin{tabular}{|c|c|c|c|c|c|c|c|}
\hline No & $\begin{array}{l}\text { Nama } \\
\text { Aplikasi/Sit } \\
\text { us web }\end{array}$ & $\begin{array}{c}\text { Kota/Kabu } \\
\text { paten }\end{array}$ & Platform & $\begin{array}{l}\text { Kategori } \\
\text { Inovasi } \\
\text { (orde- I) }\end{array}$ & $\begin{array}{l}\text { Situs } \\
\text { web }\end{array}$ & Fungsi & Pengembang \\
\hline 1 & Mata Kota & $\begin{array}{l}\text { Kota besar } \\
\text { (nasional) }\end{array}$ & $\begin{array}{l}\text { Smart } \\
\text { phonel } \\
\text { Android; } \\
\text { iOS }\end{array}$ & $\begin{array}{l}\text { Pencegah } \\
\text { an } \\
\text { kriminalita } \\
\text { s }\end{array}$ & $\begin{array}{l}\text { www. } \\
\text { matak } \\
\text { ota.id }\end{array}$ & $\begin{array}{l}\text { Matakota akan bekerja } \\
\text { sama dengan beberapa } \\
\text { instansi seperti pemerintah } \\
\text { kota, kepolisian, rumah } \\
\text { sakit, pemadam kebakaran } \\
\text { dan SAR agar dapat } \\
\text { menindaklanjuti laporan } \\
\text { keadaan darurat }\end{array}$ & Matakota \\
\hline 2 & $\begin{array}{l}\text { Jakarta City } \\
\text { Line }\end{array}$ & Jakarta & $\begin{array}{l}\text { Smart } \\
\text { phonel } \\
\text { Android; } \\
\text { iOS }\end{array}$ & $\begin{array}{l}\text { Transport } \\
\text { asi publik }\end{array}$ & - & $\begin{array}{l}\text { informasi seputar KRL dan } \\
\text { aduan/keluhan dari } \\
\text { pengguna }\end{array}$ & \\
\hline 3 & $\begin{array}{l}\text { Transit } \\
\text { Jakarta KRL } \\
\text { Navitime }\end{array}$ & Jakarta & $\begin{array}{l}\text { Smart } \\
\text { phonel } \\
\text { Android; } \\
\text { iOS }\end{array}$ & $\begin{array}{l}\text { Transport } \\
\text { asi publik }\end{array}$ & - & $\begin{array}{l}\text { informasi seputar KRL, } \\
\text { kedatangan, dan } \\
\text { keberangkatan }\end{array}$ & \\
\hline 4 & Go-Jek & $\begin{array}{l}\text { Kota besar } \\
\text { (nasional) }\end{array}$ & $\begin{array}{l}\text { Smart } \\
\text { phonel } \\
\text { Android; } \\
\text { iOS }\end{array}$ & Ekonomi & - & $\begin{array}{l}\text { Mempertemukan konsumen } \\
\text { dan driver (gojek/car) } \\
\text { melalui peta yang } \\
\text { ditampilkan dalam aplikasi. } \\
\text { Perusahaan menggunakan } \\
\text { konsep berbagai ekonomi } \\
\text { dimana aset dimiliki oleh } \\
\text { individu yang bekerja untuk } \\
\text { dirinya dan berbagi hasil } \\
\text { kepada perusahaan }\end{array}$ & \\
\hline 5 & $\begin{array}{l}\text { X-Igent } \\
\text { panic button }\end{array}$ & Bandung & $\begin{array}{l}\text { Smart } \\
\text { phonel } \\
\text { Android; } \\
\text { iOS }\end{array}$ & $\begin{array}{l}\text { Pencegah } \\
\text { an } \\
\text { kriminalita } \\
\text { s }\end{array}$ & $\begin{array}{l}\text { http:/ } \\
\text { /x- } \\
\text { igent.c } \\
\text { om/ }\end{array}$ & $\begin{array}{l}\text { Individu mengakses aplikasi } \\
\text { dengan memasukkan Id dan } \\
\text { alamat lokasi. Individu } \\
\text { dapat menekan tombol } \\
\text { panic jika merasa atau } \\
\text { mengetahui kondisi darurat } \\
\text { disekitar mereka. Informasi } \\
\text { lokasi (geotag) akan } \\
\text { terkirimkan ke pusat (BCC) } \\
\text { untuk selanjutnya ditindak } \\
\text { lanjuti }\end{array}$ & $\begin{array}{c}\text { Bandung } \\
\text { Digital Valley }\end{array}$ \\
\hline 6 & $\begin{array}{l}\text { Jogja } \\
\text { Istimewa }\end{array}$ & $\begin{array}{l}\text { D.I. } \\
\text { Yogyakarta }\end{array}$ & $\begin{array}{l}\text { Smart } \\
\text { phonel } \\
\text { Android; } \\
\text { iOS }\end{array}$ & Pariwisata & & $\begin{array}{l}\text { Aplikasi berisikan informasi } \\
\text { destinasi wisata, kuliner dan } \\
\text { event di Yogyakarta }\end{array}$ & Gamatechno \\
\hline
\end{tabular}




\begin{tabular}{|c|c|c|c|c|c|c|c|}
\hline No & $\begin{array}{l}\text { Nama } \\
\text { Aplikasi/Sit } \\
\text { us web }\end{array}$ & $\begin{array}{c}\text { Kota/Kabu } \\
\text { paten }\end{array}$ & Platform & $\begin{array}{c}\text { Kategori } \\
\text { Inovasi } \\
\text { (orde- I) }\end{array}$ & $\begin{array}{l}\text { Situs } \\
\text { web }\end{array}$ & Fungsi & Pengembang \\
\hline 7 & $\begin{array}{l}\text { Pariwisata } \\
\text { Solo }\end{array}$ & Surakarta & Situs web & Pariwisata & $\begin{array}{l}\text { http:/ } \\
\text { /pari } \\
\text { wisata } \\
\text { solo.s } \\
\text { urakar } \\
\text { ta.go.i } \\
\text { d/jala } \\
\text { n- } \\
\text { jalan- } \\
\text { ke- } \\
\text { solo }\end{array}$ & $\begin{array}{l}\text { Portal web yang berisikan } \\
\text { Informasi mengenai } \\
\text { destinasi wisata, event, dan } \\
\text { akomodasi di Kota Solo. }\end{array}$ & \\
\hline 9 & $\begin{array}{l}\text { petabencana } \\
\text {.id }\end{array}$ & $\begin{array}{l}\text { Jakarta, } \\
\text { Bandung, } \\
\text { Surabaya }\end{array}$ & $\begin{array}{l}\text { Smart } \\
\text { phonel } \\
\text { Android; } \\
\text { iOS }\end{array}$ & $\begin{array}{l}\text { Mitigasi } \\
\text { bencana }\end{array}$ & $\begin{array}{l}\text { https: } \\
\text { //pet } \\
\text { abenc } \\
\text { ana.id } \\
\text { / }\end{array}$ & $\begin{array}{l}\text { Berbagi informasi dan } \\
\text { pelaporan kejadian } \\
\text { kebencanaan seperti banjir, } \\
\text { gempa, dll dan untuk dapat } \\
\text { ditanggapi oleh masyarakat, } \\
\text { pemerintah, dan LSM }\end{array}$ & $\begin{array}{l}\text { US Aid; MIT } \\
\text { urban Risk } \\
\text { Lab }\end{array}$ \\
\hline . & \multicolumn{7}{|c|}{ Berlanjut (hingga nomor 338) } \\
\hline 337 & $\begin{array}{l}\text { Solid Waste } \\
\text { Application } \\
\text { Transportati } \\
\text { on (SWAT) }\end{array}$ & Surabaya & - & & $\begin{array}{l}\text { www. } \\
\text { dkp.su } \\
\text { rabaya } \\
\text {.go.id }\end{array}$ & $\begin{array}{l}\text { Mengontrol dan memonitor } \\
\text { pergerakan truk } \\
\text { pembuangan dari } \\
\text { lingkungan permukiman ke } \\
\text { TPS dan TPA Benowo }\end{array}$ & \\
\hline
\end{tabular}

Sumber: Analisis, 2018

Inovasi aplikasi/situs web juga berusaha untuk mengatasi permasalahan kriminalitas perkotaan. Dari sisi infratruktur TIK, kriminalitas ditekan dengan penggunaan CCTV publik dan privat yang terpasang pada ruang luar. CCTV publik milik pemerintah kota juga difungsikan untuk memonitor kondisi lalu lintas. Namun hal ini, sebagai contoh di Kota Bandung, masih terbatas pada operasi yang manual. Aplikasi untuk menekan kriminalitas juga bertumpu pada manusia itu sendiri sebagai sensor, aplikasi Panic Buton, Go-Sigap memungkinkan individu untuk mentransmisikan keadaan bahaya atau melaporkan kondisi bahaya /kriminalitas yang terjadi di sekitar mereka. Mitigasi bencana alam dilakukan dengan aplikasi Z-alert, petabencana.id, dan beberapa aplikasi yang berkaitan dengan pelaporan seperti "Pasangmata". Bencana alam yang berulang seperti banjir di perkotaan dapat dimonitor dalam pentabencana.id yang aktif di kota Jakarta, Bandung, dan Surabaya, sedangkan bencana gempa bumi dilaporakan secara interaktif oleh aplikasi Earthquake Alert. Aplikasi peta bencana.id memungkinkan masyarakat untuk melaporkan lokasi terjadinya banjir/genangan dan juga lokasi evakuasi (Kusumo, 2016). Beberapa aplikasi/situs web lain diciptakan untuk menunjang kehidupan (QoL) masyarakat kota seperti yang ditemukan pada kategori pariwisata/budaya, kesehatan, dan pendidikan. 
Tabel 2. Klasifikasi Inovasi Aplikasi/Situs web Pendukung Smart City.

\begin{tabular}{|c|c|c|c|}
\hline Kode & Kategori Inovasi SC(Oder-II) & Jumlah & Contoh Aplikasi/Situs web \\
\hline A & Lapangan pekerjaan & 3 & Bursa Kerja online (disnaker.bandung.go.id), ayo kerja, ECC \\
\hline B & Transportasi dan Lalulintas & 8 & $\begin{array}{l}\text { ACTS, sits.dishub.surabaya.go.id, TransMetro Pekanbaru, } \\
\text { Jakarta City Line, Boseh / bike sharing }\end{array}$ \\
\hline $\mathrm{C}$ & Pendidikan & 6 & digiSchool, schoomedia.id, Edubox \\
\hline $\mathrm{D}$ & Partisipasi masyarakat & 11 & SINOVIK, Qlue, SIP Bandung Juara, Iuran.id, Jogjaplan \\
\hline $\mathrm{E}$ & Pengelolaan sampah & 4 & Gringgo, SWAT \\
\hline F & Birokrasi/Kepemerintahan & 17 & $\begin{array}{l}\text { Whistle Blowing System (wbs.bandung.go.id/), Surat } \\
\text { Online, BIRMS (birms.bandung.go.id), }\end{array}$ \\
\hline G & Kepegawaian & 4 & Absensi Online (Garbis), SILAKIP Bandung, bdg E-RK \\
\hline $\mathrm{H}$ & Perijinan & 10 & $\begin{array}{l}\text { Surabaya Single Window, Pelayanan PBB online \& e- } \\
\text { SATRIA,i-PBB,dpmptsp.bandung.go.id }\end{array}$ \\
\hline I & Kesehatan & 7 & $\begin{array}{l}\text { SIP Online, Aplikasi Bandung Sehat (siwaras), Medi-Call, } \\
\text { eHealth Surabaya }\end{array}$ \\
\hline $\mathrm{J}$ & Manajemen energi & 1 & PJU Online \\
\hline $\mathrm{K}$ & Mitigasi bencana alam & 5 & petabencana.id, Z-Alert, Earthquake Alert \\
\hline $\mathrm{L}$ & Pencegahan kriminalitas & 4 & Panic Buton, Go-Sigap, Pasangmata, iVMS 4500 \\
\hline $\mathbf{M}$ & Start-up/ kewirausahaan & 3 & $\begin{array}{l}\text { e-commerce denpasar, Ekonomi Kreatif Bogor, Startup } \\
\text { makasar expo }\end{array}$ \\
\hline $\mathbf{N}$ & Pariwisata dan budaya & 6 & Jogja Istimewa, Pariwisata Solo, e-Wisata Makassar \\
\hline
\end{tabular}

Sumber: Analisis, 2018

\section{Pemetaan Kategori Aplikasi/Situs Web ke dalam Dimensi Smart City}

Pemetaan kategori aplikasi/situs web pendukung $S C$ ke dalam dimensi SC Giffinger et al., (2007) ditampilkan pada Gambar 3. Dari 14 kategori inovasi, pemasangan dengan dimensi $S C$ menghasilkan delapan dimensi $S C$ yang terdiri dari enam dimensi awal $S C$ Giffinger et al. (2007) dan dua dimensi usulan yang merupakan hasil penambahan dari temuan empiris. Dua dimensi usulan tersebut adalah Smart Energi Manajemen dan Smart Disaster Mitigation.

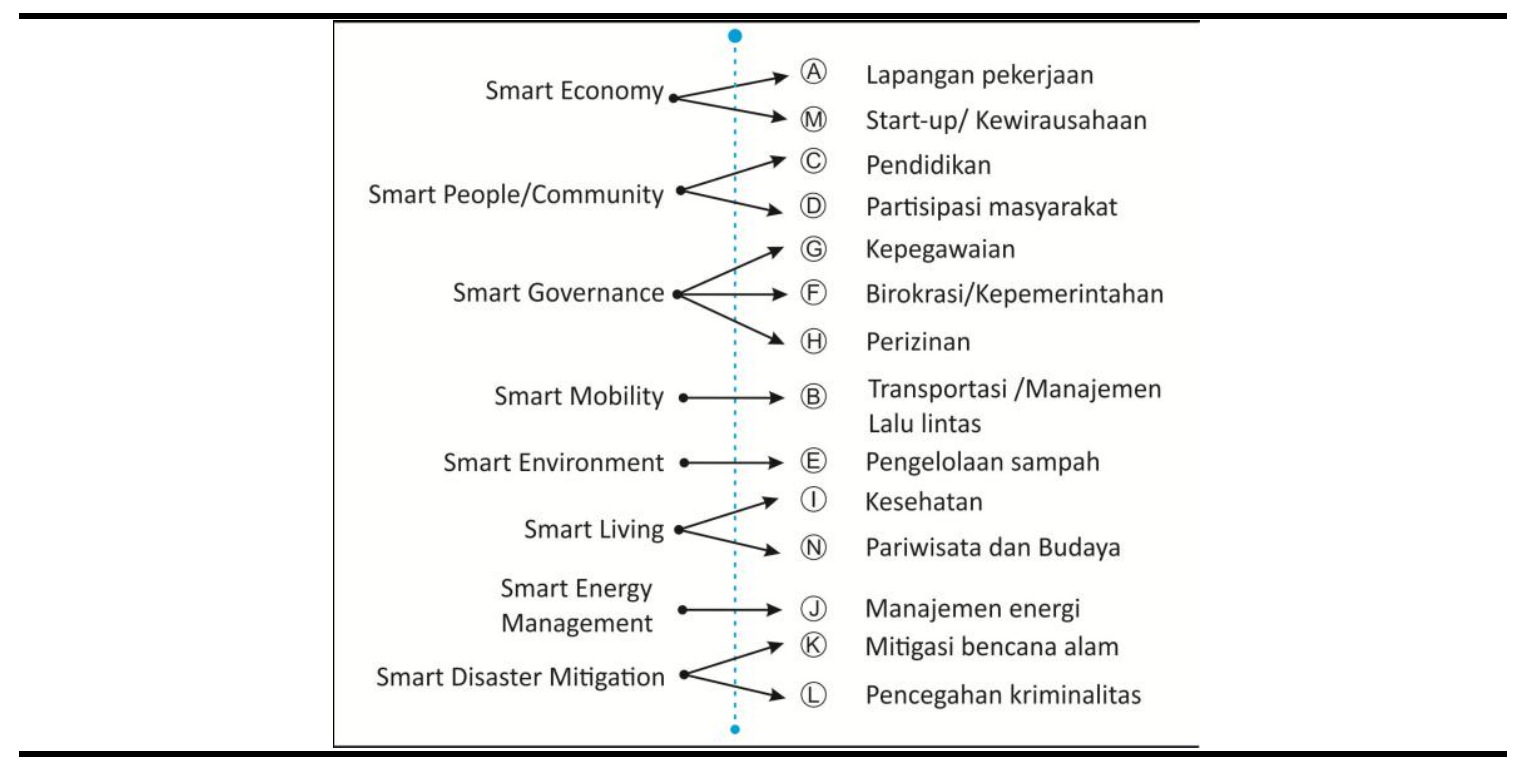

Sumber: Analisis, 2018

Gambar 3. Pemetaan Tipologi Aplikasi/Situs web dalam Dimensi Smart City 
Dimensi Smart Disaster Mitigation terkait inovasi mitigasi bencana alam dan bencana kemanusiaan/crime prevention. Aplikasi/situs web seperti Panic Button, Pasang Mata, petabencana.id, Z-Alert, dan lainnya yang sejenis merupakan inovasi konkrit yang telah diimplementasikan oleh pemerintah kota untuk mengatasi masalah terkait kebencanaan dan kriminalitas. Hal ini serupa dengan usulan Djunaedi (2014) terkait penambahan dimensi Smart Disaster Mitigation untuk merespon berkembangnya dinamika kebencanaan di Indonesia. Sistem cerdas peringatan dini kebencanaan harus terintegrasi dalam konsep $S C$ yang diimplementasikan pada kota-kota yang berada pada kawasan rawan bencana.

Smart Energy Management berkaitan dengan manajemen/monitoring sumber daya yang dikonsumsi oleh kota seperti listrik, air, dan gas. Pada contoh Kota Bandung, implementasi Smart Energy masih sangat infant yaitu berupa pemantauan penerangan jalan umum (PJU) secara online untuk efisiensi tenaga listrik. Penerapan konsep Smart Energy secara komprehensif dapat disebut smart yang memerlukan kesiapan TIK, sensor, dan aktuator yang canggih untuk dapat melakukan sensing, analysis, dan acting untuk memenuhi flow dan demand energi (Mosannenzadeh et al., 2017)

Implementasi Smart Environment di Indonesia terbatas pada pengelolaan sampah 3R dan terpadu secara digital, sedangkan Smart Living berkaitan dengan QoL masyarakat seperti pelayanan pendidikan, kesehatan, dan pariwisata/ event budaya. Smart Economy, dilain sisi fokus pada inovasi kegiatan ekonomi baru yang mempertemuan penawaran dan permintaan dan juga pemenuhan kebutuhan lapangan pekerjaan. Dari klasifikasi inovasi kedalam dimensi SC belum terlihat secara empiris pendekatan Smart Infrastructur dalam manajemen kota. Meskipun secara operasional Smart Infrastructur berkaitan erat dengan manajemen energi kota, namun dalam perspektif implementatif Smart Infrastructur lebih menekankan bagaimana infrastrukur digital mampu menganalisis dan memberikan informasi untuk pengambilan keputusan dalam manajemen kota (Finger, 2017).

\section{KESIMPULAN}

Implementasi Smart City pada kota-kota di Indonesia menggunakan kombinasi unsur TIK dan Internet of Thing (IoT) yang berwujud aplikasi maupun situs web. Secara agregat, terkoleksi 338 inovasi $S C$ namun hanya hanya 109 inovasi yang berbentuk aplikasi dan situs web. Surabaya, Bandung, dan Jakarta tercatat sebagai kota yang tercatat telah mengimplementasikan inovasi aplikasi dan situs web terbanyak ( $>25$ aplikasi/situs web) dan paling lengkap (menjangkau hampir sebagian besar dimensi SC. Dari 109 inovasi aplikasi/situs web dapat diklasifikasikan kedalam 14 kategori fungsi dalam solusi permasalahan dan manajemen perkotaan. Secara empiris, dimensi $S C$ yang ada di Indonesia telah mengakomodasi enam dimensi awal yang dikemukakan oleh Giffinger et al. (2007) dengan penambahan dua dimensi baru yaitu Smart Energy Management dan Smart Disaster Mitigation (Djunaedi, 2014) - dimana dua dimensi tersebut telah diimplementasikan secara terbatas di Indonesia.

Aplikasi/situs web memiliki cara kerja yang spesifik untuk mengatasi permasalahan perkotaan. Secara umum kesamaan cara kerja ditunjukkan pada aplikasi/situs web yang berada pada tipologi yang sama. Terlebih lagi, modul aplikasi/situs web bekerja pada lansekap digital yang memerlukan instrument jejaring nir kabel (IoT), sensor dan aktuator, operator, dan aplikasi/situs web sebagai intermediator informasi dengan pengguna (user). Terkait hal ini, artikel ilmiah ini menyarankan adanya riset lebih lanjut yang fokus terhadap ekosistem dan cara kerja aplikasi/situs web secara komprehensif sesuai dengan tipologinya dalam mengelola kota, terlebih pada eksplorasi data besar (bigdata). Pemanfaatan bigdata dalam perencanaan kota menuntut adanya kebijakan data terbuka (open-data) untuk peluang riset-riset geo-spasial big data di kota-kota di Indonesia yang hingga saat ini telah memanfaatkan variasi aplikasi/situs web pendukung $S C$. 


\section{UCAPATAN TERIMA KASIH}

Penelitian ini dapat dilaksanakan atas dukungan penuh dari dana hibah Departemen Teknik Arsitektur dan Perencanaan (DTAP), Fakultas Teknik, UGM. Peneliti mengucapkan terimakasih kepada Center for Digital Society (CfDS) atas bantuan data-data proyek yang dipakai dalam penelitian ini. Tidak lupa terima kasih kepada Direktur DSSDI UGM atas waktu yang diberikan untuk diskusi dan sharing pengetahuan dalam pengembangan analisis dan penulisan dalam penelitian ini.

\section{DAFTAR PUSTAKA}

Anggini, T. (2016). Pemanfaatan Media Center Dalam Pelayanan Publik Sebagai Upaya Mewujudkan Surabaya Smart City. Universitas Gadjah Mada.

Anthopoulos, L. (2016). Smart utopia VS smart reality: Learning by experience from 10 smart city cases. Cities, 63, 128-148. http://doi.org/http://dx.doi.org/10.1016/j.cities.2016.10.005

Arup. (2010). Smart Cities Transforming the 21st century city via the creative use of technology. Smart Cities (Vol. 16). London. Retrieved from http://publications.arup.com/Publications/S/Smart_Cities.aspx

Cicirelli, F., Guerrieri, A., Spezzano, G., \& Vinci, A. (2017). An edge-based platform for dynamic Smart City applications. Future Generation Computer Systems, $76, \quad 106-118$. http://doi.org/10.1016/j.future.2017.05.034

Crooks, A., Pfoser, D., Jenkins, A., Croitoru, A., Stefanidis, A., Smith, D., ... Lamprianidis, G. (2015). Crowdsourcing urban form and function. International Journal of Geographical Information Science, (April), 37-41. http://doi.org/10.1080/13658816.2014.977905

Djunaedi, A. (2014). Smart City : Solusi Permasalahan Masa Depan Perkotaan di Indonesia (Sebuah Agenda Penelitian). In Seminar Nasional Smart City: Solusi untuk Permasalahan Perkotaan di Indonesia? (pp. 15). Yogyakarta, Indonesia: PSPPR UGM.

Finger, M. (2017). Smart Cities - Management of Smart Urban Infrastructures | Coursera. Retrieved April 19, 2017, from https://www.coursera.org/learn/smart-cities/home/welcome

Geertman, S., Ferreira, J. J., Goodspeed, R., \& Stillwell, J. (2015). Planning Support Systems and Smart Cities. (J. Stillwell, Ed.). Springer. http://doi.org/DOI 10.1007/978-3-319-18368-8

Giffinger, R., Fertner, C., Kramar, H., \& Meijers, E. (2007). Smart cities Ranking of European medium-sized cities. October (Vol. 16). Vienna. http://linkinghub.elsevier.com/retrieve/pii/S026427519800050X

Graham, S., \& Aurigi, A. (1997). Urbanising cyberspace? City, 2(7), 18-39. http://doi.org/10.1080/13604819708900051

Hollands, R. G. (2008). Will the real smart city please stand up? City, 12(3), 303-320. http://doi.org/10.1080/13604810802479126

Kunzmann, K. R. (2014). Smart Cities : a New Paradigm of Urban Development. Crios, 7, 9-19. http://doi.org/DOI:10.7373/77140

Lv, Z., Song, H., Basanta-Val, P., Steed, A., \& Jo, M. (2017). Next-Generation Big Data Analytics: State of the Art, Challenges, and Future Research Topics. IEEE Transactions on Industrial Informatics, 3203(c), 1-1. http://doi.org/10.1109/TII.2017.2650204

Mayangsari, L., \& Novani, S. (2015). Multi-stakeholder co-creation Analysis in Smart city Management: An Experience from Bandung, Indonesia. Procedia Manufacturing, 4(Iess), 315-321. http://doi.org/10.1016/j.promfg.2015.11.046

Mosannenzadeh, F., Bisello, A., Vaccaro, R., D’Alonzo, V., Hunter, G. W., \& Vettorato, D. (2017). Smart energy city development: A story told by urban planners. Cities, 64, 54-65. http://doi.org/10.1016/j.cities.2017.02.001

Murty, R. N., Mainland, G., Rose, I., Chowdhury, A. R., Gosain, A., Bers, J., \& Welsh, M. (2008). CitySense: An Urban-Scale Wireless Sensor Network and Testbed. Technologies for Homeland Security, 2008 IEEE Conference On, 583-588. http://doi.org/10.1109/THS.2008.4534518

Mutiara, D., Yuniarti, S., \& Pratama, B. (2018). Smart Governance for Smart City. IOP Conf. Series: Earth and Environmental Science, 126(1), 1-10. http://doi.org/10.1088/1755-1315/

Nam, T., \& Pardo, T. a. (2011). Conceptualizing smart city with dimensions of technology, people, and institutions. Proceedings of the 12th Annual International Digital Government Research, 282. http://doi.org/10.1145/2037556.2037602 
Pandini, I. (2016). Kajian Pengembangan Kota Bandung Dalam Mengimplementasikan Smart City. Universitas Gadjah Mada.

Picon, A. (2015). SmartCities, A Spatialised Intelligence. (H. Castle \& M. Murphy, Eds.) (First edit). Chichester: John Willey \& Sons.Inc.

Rathore, M. M., Ahmad, A., Paul, A., \& Rho, S. (2016). Urban planning and building smart cities based on the Internet of Things using Big Data analytics. Computer Networks, 101, 63-80. http://doi.org/10.1016/j.comnet.2015.12.023

Sarma, S., \& Sunny, S. A. (2017). Civic entrepreneurial ecosystems: Smart city emergence in Kansas City. Business Horizons, 60(6), 843-853. http://doi.org/10.1016/j.bushor.2017.07.010

Smart London Board. (2013). Smart London Plan: Using the creative power of new technologies to serve London and improve Londoners' lives, 54.

Sofeska, E. (2017). Understanding the Livability in a City Through Smart Solutions and Urban Planning Toward Developing Sustainable Livable Future of the City of Skopje. Procedia Environmental Sciences, 37, 442453. http://doi.org/http://dx.doi.org/10.1016/j.proenv.2017.03.014

UN-Habitat. (2006). State of the World's Cities in 2006. Retrieved from http://mirror.unhabitat.org/pmss/listItemDetails.aspx?publicationID=2101 